DOI 10.31558/2519-2949.2020.2.18

УДК 32.019.51:323.28(569.4)

ORCHID ID: https://orcid.org/0000-0002-6639-6517

Трегубов Д. М., Воєнно-дипломатична академія імені Свгенія Березняка

\title{
ПОЛІТИКА ІЗРАЇЛЮ ЩОДО ОБМЕЖЕННЯ ПРАВ ВЛАСНОСТІ ЧЛЕНІВ СІМЕЙ ТЕРОРИСТІВ
}

\begin{abstract}
В статті розкриті деякі аспекти політики Ізраїлю щодо боротьби з терористичними загрозами. Зокрема, розглянуто досвід покладання иивільно-правової відповідальності на членів сімей терористів шляхом знищення їх будинків. Ізрайль використовує багаторівневу систему боротьби з тероризмом та має великий практичний досвід у реалізації політики проведення антитерористичних заходів, щуо може бути цікавим для України. Також, в статті «Політика Ізраӥлю щодо обмеження прав власності членів сімей терористів» частково проаналізовано міжнародну нормативно-правову базу, що регламентує застосування жорстких обмежувальних заходів до терористів та їх родичів.

В умовах гібридної агресії Російської Федераиї проти України актуальним є питання організації ефективної протидії вітчизняних силових структур сектора безпеки та оборони терористичним атакам з боку військових формувань самопроголочених ЛНР та ДНР. В умовах складної політичної ситуачії перед Україною постали загрози, що вимагають удосконалення функиіонування загальнодержавної політики боротьби з тероризмом. Відповідна робота має здійснюватися з використанням досвіду та дієвих світових практик, зокрема Ізраїлю.

Незважаючи на триваючу внутрішньополітичну кризу в Ізраїлі, уряд країни чітко усвідомлюе необхідність жорстких антитерористичних заходів і тому навряд чи відмовиться від практики знесення будинків терористів, хоча ї̈ ефективність залишається під питанням.

Не виключається, що через певний період часу на фоні зростання рівня терористичних загроз в Свропі, деякі провідні краӥни світу можуть взяти приклад Ізраїлю, запозичивщи його політику покладання відповідальності на родичів терористів. У короткостроковій перспективі такі радикальні заходи спроможні дати позитивний ефект, однак їх фактична невідповідність принципам функиіонування правової держсави і міжнародного співтовариства сприятимуть загостренню конфліктів, які спровокують нову хвилю терористичної загрози.
\end{abstract}

Ключові слова: Ізраӥль, політика, тероризм, права людини, знесення будинків, ЦАХАЛ, відповідальність.

Постановка проблеми в загальному вигляді. В умовах гібридної агресії Російської Федерації проти України актуальним є питання організації ефективної протидії вітчизняних силових структур сектора безпеки та оборони терористичним загрозам з боку військових формувань самопроголошених ЛНР та ДНР. Політика РФ спрямована на дестабілізацію ситуації в Україні, в тому числі шляхом інспірування сепаратистських проявів і всебічної підтримки диверсійнотерористичної діяльності маріонеткових квазідержавних утворень на тимчасово окупованих територіях у Донецькій та Луганській областях.

Останнім часом ймовірність поширення тероризму в Україні набуває загрозливого характеру, чому сприяють:

- активізація в Україні сепаратистських рухів та провокування таких настроїв у місцях компактного проживання національних меншин;

- наявність на території України великої кількості уразливих об'єктів для можливих терористичних посягань;

- зростання рівня злочинності, пов'язаної з незаконним обігом вогнепальної зброї, боєприпасів, вибухових і отруйних речовин та інших засобів масового ураження;

- внутрішні міграційні процеси, у тому числі спричинені збройною агресією Російської Федерації проти України, а також триваючою міграційною кризою у світі.

Терористичні загрози, що постали перед Україною, вимагають удосконалення функціонування загальнодержавної політики боротьби з тероризмом. Відповідна робота має здійснюватися 
з використанням досвіду та дієвих світових практик у сфері боротьби з тероризмом, зокрема Ізраїлю.

Аналіз останніх досліджень та публікацій. Для аналізу було розглянуто окремі аспекти політики Ізраїлю щодо боротьби з терористичними загрозами [1]. Джерельну базу становлять наукові праці стосовно особливостей правового регулювання i покладання цивільно-правової відповідальності на членів сімей терористів [2]. Актуальні питання протидії тероризму досліджують українські та іноземні автори, зокрема, О. Резнікова, А. Місюра, С. Дрьомов, К. Войтовський, Д. Гордіс [4], Ю. Данильченко [5].

На сьогодні звинувачення з боку міжнародного співтовариства у відношенні Ізраїлю стосуються неприпустимості колективної відповідальності за здійснений злочин. При цьому, терористичні загрози, що постали перед Україною, вимагають удосконалення функціонування загальнодержавної системи боротьби з тероризмом, зокрема, посилення відповідальності за терористичну діяльність $[6,7]$.

Мета статті. Проаналізувати доцільність використання досвіду застосування державою Ізраїль (уповноваженими органами) політики знесення будинків терористів та їх сімей в умовах високого рівня терористичної загрози і гібридної агресії Російської Федерації проти України.

Виклад основного матеріалу. Ізраїль - держава, яка з самого початку свого існування вимушена протидіяти терористичним атакам, використовуючи багаторівневу систему боротьби 3 тероризмом та великий практичний досвід у реалізації антитерористичних заходів. Особливістю роботи силових структур Ізраїлю є високий рівень професійної підготовки співробітників, широка довіра до них серед населення та розгалужена мережа інформаторів. При цьому, більшість пересічних ізраїльських громадян готові до дій у екстрених ситуаціях. Так, у разі необхідності, в момент вчинення терористичного акту до терориста можуть застосовувати зброю силовики, охоронці приватних структур, а також громадяни, що мають право на носіння вогнепальної зброї (незважаючи на достатньо суворе законодавство щодо застосування зброї). Поєднання зусиль органів державної влади і суспільства у боротьбі з тероризмом є досить ефективним елементом системи протидії.

Країна має унікальний досвід контртерористичної боротьби, оскільки доводиться реагувати на велику кількість терористичних загроз. Терористична атака може статися як на території Ізраїлю, так і з території Палестини або країн близького і далекого зарубіжжя. Злочинці відрізняються один від одного за національністю та віросповіданням, проте частіше за усе, Ізраїль має справу з бойовиками арабського (палестинського) походження. Серед іншого трапляються випадки викрадення ізраїльських військовослужбовців, здійснення ножових нападів, атаки 3 використанням автомобіля, а також розстріли людей і підриви різноманітних вибухових пристроїв у громадських місцях [9].

Одним здієвих інструментів боротьби з тероризмом в Ізраїлі вважається покладання цивільно-правової відповідальності на злочинців. Здійснюється це різними способами, одним 3 яких є встановлення значних штрафів та пред'явлення позовів щодо відшкодування збитків як від імені держави, так і від імені родичів потерпілих. Крім цього у законодавстві Ізраїлю прямо передбачено знищення майна (в першу чергу об'єкту нерухомості - житлового будинку) близьких родичів терористів (ст. 119 Закону про оборону в надзвичайних ситуаціях). Норма закону про знесення будинків може застосовуватися до родичів терористів-смертників, а також до родичів тих бойовиків, внаслідок дій яких постраждали, були вбиті або поранені громадяни Ізраїлю. Відповідне рішення приймається військовим командуванням Ізраїлю, в зоні відповідальності якого знаходиться населений пункт, де мешкав терорист. Родина терориста може опротестувати такі дії влади протягом 72 годин після оголошення рішення. На цей час блокуються та опечатуються (іноді повністю замуровуються) всі входи і виходи з будинку (житлового приміщення), що підлягає руйнуванню. Подібна політика ізраїльських силових структур заснована на особливостях підходу до особистості терориста-смертника, якого втратою власного життя не налякати.

Довідка. Як правило, психологічна обробка кандидатів на здійснення терористичного злочину трунтується на залученні до глобального братерства молодих, соиіально знедолених, особисто або колективно принижених, погано освічених осіб, щуо, нібито, дає безліч преференцій: гроші, влада, почуття сили та переваги над іншими. Психологічна установка на долучення до окремої згуртованої сочіальної групи акцентується на тому, щзо смерть не є страшною, а здійснення терористичного акту робить його виконавця обраним вищчим силами. 
Ізраїльські правила знесення будинків родичів терориста мають свою специфіку, що обумовлена особливостями правової системи єврейської держави, яка складається $з$ елементів національного традиціоналізму (дотримання «галахи»- сукупності релігійних законів і правил юдаїзму, які є основним джерелом права) і судового прецеденту (рішення Верховного Суду Ізраїлю також є джерелом права, виступаючи прецедентом). Таким чином, знищення власності трактується як продовження законного права на помсту. У той же час з урахуванням того, що законом передбачається оскарження дій військової адміністрації в Верховному Суді Ізраїлю, теоретично рішення щодо знищення майна родичів терористів може зазнавати змін.

Політика руйнування будинків терористів $є$ достатньо суперечливою, іiі доцільність і правовий статус постійно обговорюється. Вперше таку тактику застосувала британська армія в Південній Африці під час 2-ої англо-бурської війни (1899р. - 1902 р.). Бурські загони вели партизанську війну проти англійців, здійснюючи диверсії з метою руйнування інфраструктури, у відповідь британська влада віддала розпорядження про руйнування будинків, розташованих поблизу від тих місць, де відбувалися диверсії, для запобігання подальших інцидентів [8].

Згодом англійці стали використовувати цю тактику в Палестині. Так, наприкінці 1945 р., у відповідь на атаки партизан, що належали як до арабських, так i до єврейських підпільних військових організацій, британська влада почала застосовувати руйнування будинків бойовиків. При цьому, англійці жодного разу не знищіли житло єврейських бойовиків, навіть після їх терористичної атаки в липні 1946 p. і потужного вибуху в єрусалимському готелі «King David», де була розташована штаб-квартира британської адміністрації в Палестині.

У 1967 р. в Ізраїлі був прийнятий закон про знесення будинків терористів, однак він дещо відрізнявся від політики англійців. Зокрема, ізраїльський закон дозволяв зносити будинки тільки в тому випадку, якщо саме житло використовувалося як штаб, де відбувалося планування i підготовка теракту. Норми зазначеного закону активно застосовувалися Ізраїлем проти терористів з початку першої палестинської інтифади у 1987 р. Так, Армія оборони Ізраїлю (ЦАХАЛ) зіткнулася 3 новими загрозами: не з підрозділами армій Єгипту, Йорданії і Сирії, а з бойовиками озброєними камінням і саморобною зброєю. Відбувалися вибухи в автобусах і кафе, населення Ізраїлю охопила паніка. В умовах колосального політичного тиску з боку влади армія намагалася опанувати ситуацію. Відсутність у військових достатнього досвіду й інструментів боротьби з терористами, які не дорожать своїм життям, спонукала керівництво ЦАХАЛ шукати ефективні заходи протидії. Ізраїльська влада взяла за зразок практику британської адміністрації та дозволила армії знесення будинків бойовиків та їх близьких родичів, навіть якщо вони не мали безпосереднього відношення до теракту. Метою такого рішення військово-політичного керівництва Ізраїлю було здійснення психологічного тиску на терористів та їх оточення.

3 моменту прийняття закону у 1967 р. палестинці, чиї будинки були призначені до зносу, не мали ніякої можливості подачі апеляції, лише у 1989 р. Верховний суд Ізраїлю ухвалив надати можливість мешканцям будинків подавати апеляцію та прохання про анулювання розпорядження про знесення, за винятком періодів дії воєнного стану. Однак на практиці Верховний суд майже не втручався в рішення військового командування.

Практика знесення будинків застосовувалася досить часто. Під час першої інтифади (з 1987 р. по 1993 р.) було зруйновано 433 будинки бойовиків, а близько 280 будинків були заблоковані для проживання. Після закінчення інтифади застосування практики знищення помешкань було призупинено. Зокрема, 31998 р. по 2000 р. жоден будинок не був знесений. 3 початком другої інтифади у вересні 2000 р. практика руйнувань житлових будівель терористів та їх родичів відновилася.

У 2005 р., коли рівень ізраїльсько-палестинського протистояння в рамках другої інтифади відчутно знизився, начальник Генерального штабу ЦАХАЛ Моше Яалон віддав розпорядження щодо створення спеціальної комісії для розгляду правових аспектів і аналізу ефективності політики знесення будинків. Звіт про результати розслідування комісії так і не був опублікований, проте в ізраїльських 3МІ з'явилася інформація, що комісія висунула аргументи на користь скасування заходів з руйнування помешкань терористів. Після цього така практика була тимчасово припинена, але керівництво ЦАХАЛ залишило за собою право відновити ії, якщо надзвичайні обставини того вимагатимуть.

У 2008 р. відсутність дієвих інструментів протидії новій хвилі терактів, скоєних мешканцями Східного Єрусалиму (арабське населення Східного Єрусалиму має статус постійних жителів Ізраїлю), змусило керівництво ЦАХАЛ знову відновити практику руйнування будинків. Знесенню 
підлягали будинки терористів, а в окремих випадках - i помешкання тих, хто закликав до насильства. Родинам власників заборонялося будувати нові будинки на тих же ділянках [10].

На сьогодні звинувачення з боку міжнародної спільноти у відношенні Ізраїлю стосуються неприпустимості колективної відповідальності за злочин (Стаття 33 Женевської конвенції від 12 серпня 1949 р. - далі Конвенція). На перший погляд, це зрозумілий висновок, оскільки колективна відповідальність асоціюється з взяттям заручників, середньовіччям, іншими трагічними сторінками історії, які є практично у кожної держави. При цьому, відносно дій ізраїльської армії регулярно оприлюднюються засуджуючі прес-релізи міжнародної правозахисної організації «Нuman Rights Watch». Акцент робиться на порушеннях міжнародного права щодо неприпустимості колективних покарань і знищення приватної власності цивільних осіб. Міжнародні правозахисники здійснюють регулярний облік зруйнованої власності і постраждалих від цього членів родин терористів.

Довідка. Стаття 33 Женевської конвениії від 12 сериня 1949 р. «Про захист иивільного населення під час війни» прямо передбачає: «Жодну особу, що перебуває під захистом, не може бути покарано за правопорушення, якого вона не вчинила особисто. Колективні покарання, так само як $і$ будь-які залякування чи терор, забороняються. Пограбування забороняються. Репресалії стосовно осіб, які перебувають під захистом, та їхнього майна забороняються».

У свою чергу, Ізраїль категорично відкидає звинувачення на свою адресу, аргументуючи це тим, що діє на підконтрольних йому територіях, а положення Конвенції відносяться до збройних конфліктів міжнародного характеру [10].

Слід зазначити, що в рамках проведення кожної військової операції по знищенню будинку терориста, командування ЦАХАЛ здійснює евакуацію мешканців, що можуть постраждати від наслідків інженерних заходів (підрив або використання важкої техніки). Проте, в декількох випадків мала місце загибель людей.

Руйнування будинків часто супроводжується відеозйомкою з боку пропалестинських активістів. Вміло змонтовані відео розміщуються ними у мережі інтернет та викликають враження, що будинки руйнують не давши людям вийти назовні. Навіть коли зрозуміло, що всередині нікого немає, гірка картина ридаючих жінок, які оплакують втрату будинку, має за мету викликати у глядачів співчуття, навіть якщо ця жінка вчора спонукала свого сина стати мучеником, а завтра вона буде радіти новинам, що ізраїльський ресторан був підірваний і загинули десять молодих людей. Головною метою таких відео є створення негативного образу ЦАХАЛ та засудження дій Ізраїлю з боку світової спільноти.

Противники руйнування будинків в ізраїльському суспільстві вважають такі дії недостатньо ефективною мірою протидії тероризму, оскільки значні компенсації, які виплачують терористичні організації родичам загиблого, часто дозволяють побудувати кращий і навіть більший будинок в іншому місці. Як правило, у своєму оточенні такі сім'ї вважаються жертвами ворожого ізраїльського режиму, що підвищує їх соціальний статус.

Верховний суд Ізраїлю протягом багатьох років вважався прихильником захисту прав людини і дотримувався ліберальних поглядів, таким він залишається і сьогодні. Проте, щодо політики знесення суд найчастіше поділяв позиції керівництва ЦАХАЛ та підтримував позицію військових стосовно того, що руйнування будинків не $\epsilon$ мірою колективного покарання (не $\epsilon$ порушенням міжнародного права) і служить ефективним засобом стримування терористів [13].

У період з 2015 р. по 2018 р. в Ізраїлі відмічалася нова хвиля терористичних нападів на ізраїльтян. Палестинці активно застосовували ножові і автомобільні атаки, число жертв було достатньо високим. Не менш загрозливим став той факт, що терористичні акти почали здійснювати громадяни Ізраїлю арабського походження, що вимагало від спецслужб здійснення додаткових заходів з попередження і нейтралізації злочинів. У цьому контексті влада була стурбована можливою реакцією суспільства на знесення будинку громадянина Ізраїлю. Можливо, це стало причиною того, що суд в адміністративних справах вперше прийняв рішення про позбавлення громадянства Алья Зіуда, який вчинив автомобільні і ножові атаки на військовослужбовців ЦАХАЛ у жовтні 2015 р. Суд постановив, що, здійснюючи напади, він втратив своє право бути членом суспільства і громадянином Ізраїлю $[1,8]$.

Підводячи підсумок, можна сказати, що протягом десятиліть політика Ізраїлю стосовно знесення будинків змінювалася залежно від воєнно-політичної обстановки, активізуючись в ті моменти, коли, як здавалося, країна була позбавлена можливості застосування інших заходів впливу. Тероризм завжди присутній в повсякденному житті населення Ізраїлю, але це не означає, що 
воно змирилося з ним. У періоди жорстоких загострень конфліктів суспільство вимагало від ізраїльського уряду радикальних дій, щоб покінчити з терактами раз і назавжди. Зокрема, кар'єри двох прем'єр-міністрів - Шимона Переса і Ехуда Барака достроково закінчилися головним чином тому, що населення не відчувало впевненості в спроможності уряду забезпечити безпеку.

На теперішній час, незважаючи на триваючу внутрішньополітичну кризу в Ізраїлі, уряд прем'єр міністра Біньяміна Нетаньяху чітко усвідомлює необхідність жорсткої антитерористичної політики і тому навряд чи відмовиться від практики стримування (у т.ч. шляхом знесення будинків) терористів, хоча її ефективність залишається під питанням.

Не виключається, що через певний період часу на фоні зростання рівня терористичних загроз в Європі, деякі провідні країни світу візьмуть приклад Ізраїлю, запозичивши його політику знищення будинків терористів, ініційовану англійцями понад століття тому.

Висновки: 1. Законодавство України відрізняється від ізраїльського певною декларативністю і відсутністю реального механізму стягнення грошових коштів, доходів, цінностей, що перебувають у власності близьких родичів осіб, які вчинили терористичні акти.

2. Терористичні загрози, що постали перед Україною, вимагають удосконалення функціонування загальнодержавної системи боротьби з тероризмом, зокрема, посилення відповідальності за терористичну діяльність.

3. Формування громадської думки з метою сприяння ефективній діяльності у сфері боротьби 3 тероризмом має бути спрямовано на усвідомлення невідворотності покарання за участь у терористичній діяльності.

4. Практика знесення будинків залишається суперечливою, проте, позиція Ізраїлю грунтується на тому, що руйнування будинків не $\epsilon$ мірою колективного покарання (не $\epsilon$ порушенням міжнародного права) і служить ефективним засобом стримування терористів.

5. У короткостроковій перспективі такі радикальні заходи, як знищення будинків терористів можуть дати позитивний ефект, однак їх фактична невідповідність принципам функціонування правової держави і міжнародного співтовариства може сприяти загостренню конфліктів, які спровокують нову хвилю терористичної загрози.

Перспективи подальших досліджень. На основі досвіду застосування Ізраїлем жорсткої політики по відношенню до тероризму, розробити пропозиції щодо змін у законодавстві України у напрямку посилення відповідальності осіб, що причетні до терористичної діяльності.

\section{Бібліографічний список:}

1. Goldberg J. J. Why Jewish Terror is Different This Time // Forward. 2015. 1 Aug. URL: https://forward.com/opinion/318290/why-jewish-terror-is-different-this-time. (Дата звернення 11.04.2020).

2. Intifada of Individuals Uneasy Calm in the West Bank Following Several Violent Incidents [Electronic resource] / Haaretz. - Electronic data. - Jerusalem, 2013. - Mode of access: https://www.haaretz.com/.premiumuneasy-calm-inthe-west-bank-1.5278621. (Дата звернення 09.04.2020).

3. Резнікова О. О., Місюра А. О., Дрьомов С. В., Войтовський К. Є. Актуальні питання протидії тероризму у світі та в Україні : Аналітична доповідь. Київ : НІСД, 2017. 60 с.

4. Данильченко Ю. Б. Загальносоціальні заходи протидії тероризму. Науковий вісник публічного та приватного права. 2017. Випуск 6. Т. 2. С. 192-195.

5. Данильченко Ю. Б. Координація дій щодо протидії тероризму в Україні. Visegrad journal on human rights. 2018. № 2. Vol. 1. C. 48-53.

6. Про боротьбу з тероризмом : Закон України від 20.03.2003 p. № 638-І. Відомості Верховної Ради України. 2003. № 25. Ст. 180. (Із змінами, внесеними згідно із Законами, № 2581-VIII від 02.10.2018, BВР, 2018, № 46, ст. 371).

7. Про Концепцію боротьби з тероризмом в Україні : Указ Президента України від 05.03.2020 p. №53/2019.

8. The UN and Israel : A History of Discrimination [Electronic resource] / World Affairs. - Electronic data. Washington DC, 2013. - Mode of access:http://www.worldaffairsjournal.org/article/un-and-israel-historydiscrimination. (Дата звернення 25.03.2020).

9. Daniel Gordis, The Dubious Demolition Policy Israel Just Can't Quit. URL :

https://www.bloomberg.com/opinion/articles/2017-08-15/the-dubious-demolition-policy-israel-just-can-t-quit. (Дата звернення 15.04.2020).

10. The Israeli Governments`s Ministry of Foreign Affairs Site. URL : http://www.mfa.gov.il/MFA. (Дата звернення 11.03.2020).

11. Foreign Affairs and Defense Committee discusses Government draft law to cut tax transfers to Palestinian Authority over payouts to terrorists. URL : https://knesset.gov.il/spokesman/eng/PR_eng.asp?PRID=13720. (Дата звернення 22.03.2020). 
12. Israel: Demography 2012-2030. URL : http://web.hevra.haifa.ac.il/ chstrategy/images/publications/demography_20122030.pdf. (Дата звернення 02.04.2020).

13. Alpher N. Yossi. Periphery : Israel`s Search for Middle East Allies. - Rowman \& Littlfield, 2015. 196 p.

\section{References:}

1. Goldberg J. J. Why Jewish Terror is Different This Time // Forward. 2015. 1 Aug.

URL: https://forward.com/opinion/318290/why-jewish-terror-is-different-this-time. (Дата звернення 11.04.2020).

2. Intifada of Individuals Uneasy Calm in the West Bank Following Several Violent Incidents [Electronic resource] / Haaretz. - Electronic data. - Jerusalem, 2013. - Mode of access: https://www.haaretz.com/.premiumuneasy-calm-inthe-west-bank-1.5278621. (Дата звернення 09.04.2020).

3. Reznskova O. O., Misyura A. O., Dromov S. V., Voytovskiy K. E. Aktualni pitannya protidiyi terorizmu u sviti ta v Ukrayini : Analitichna dopovid. Kiyiv : NISD, 2017. 60 s.

4. Danilchenko Yu. B. Zagalnosotsialni zahodi protidiyi terorizmu. Naukoviy visnik publichnogo ta privatnogo prava. 2017. Vipusk 6. T. 2. S. 192-195.

5. Danilchenko Yu. B. Koordinatsiya diy schodo protidiyi terorizmu v Ukrayini. Visegrad journal on human rights. 2018. \# 2. Vol. 1. S. 48-53.

6. Pro borotbu z terorizmom : Zakon Ukrayini vid 20.03.2003 r. \# 638-I. Vidomosti Verhovnoyi Radi Ukrayini. 2003. \# 25. St. 180. (iz zminami, vnesenimi zgidno iz Zakonami, \# 2581-VIII vid 02.10.2018, VVR, 2018, \# 46, st. 371).

7. Pro Kontseptsiyu borotbi z terorizmom v Ukrayini Ukaz Prezidenta Ukrayini vid 05.03.2020 r. \#53/2019.

8. The UN and Israel : A History of Discrimination [Electronic resource] / World Affairs. - Electronic data. Washington DC, 2013. - Mode of access: http://www.worldaffairsjournal.org/article/un-and-israel-history-discrimination. (Дата звернення 25.03.2020).

9. Daniel Gordis, The Dubious Demolition Policy Israel Just Can't Quit. URL :

https://www.bloomberg.com/opinion/articles/2017-08-15/the-dubious-demolition-policy-israel-just-can-t-quit. (Data zvernennya 15.04.2020).

10. The Israeli Governments`s Ministry of Foreign Affairs Site. URL : http://www.mfa.gov.il/MFA. (Data zvernennya 11.03.2020).

11. Foreign Affairs and Defense Committee discusses Government draft law to cut tax transfers to Palestinian Authority over payouts to terrorists. URL : https://knesset.gov.il/spokesman/eng/PR_eng.asp?PRID=13720. (Data zvernennya 22.03.2020).

12. Israel: Demography 2012-2030. URL : http://web.hevra.haifa.ac.il/ ch-strategy/images/publications /demography_20122030.pdf. (Data zvernennya 02.04.2020).

13. Alpher N. Yossi. Periphery : Israel`s Search for Middle East Allies. - Rowman \& Littlfield, 2015. 196 p.

\section{Trehubov D. M. Israel's policy on restricting property rights of members of terrorist families}

The article describes some aspects of Israel's anti-terrorist policies. In particular, the experience of civil liability of terrorist family members through the demolition of their homes was examined. Israel uses a multi-level system of combating terrorism and has extensive practical experience in implementing the policy of anti-terrorism measures, which may be interesting for Ukraine. Also, the article «Israel's policy on restricting property rights of members of terrorist families» partly examined the international regulatory framework governing the application of severe restrictive measures to terrorists and their relatives.

In the context of the hybrid aggression of the Russian Federation against Ukraine, the urgent issue is the organization of effective counteraction by domestic security and defense sector security forces to terrorist attacks by military units of the self-proclaimed LPR and DPR. In a difficult political situation Ukraine faced with the threat that require an improvement in the functioning of the national counterterrorism policy. Corresponding work should be carried out using experience and effective world practices, including Israel.

Despite the ongoing domestic political crisis in Israel, the country's government is clearly aware of the need for a tough counterterrorism efforts and therefore is unlikely to abandon the practice of demolishing terrorist houses, although its effectiveness remains in question.

It is possible that after a certain period of time, against the backdrop of an increase in the level of terrorist threats in Europe, some of the leading countries of the world can follow the example of Israel, borrowing its policy of imposing responsibility on the relatives of terrorists. In the short term, such radical measures can have a positive effect, however, their actual inconsistency with the principles of the rule of law and the international community can aggravate the conflicts that will provoke a new wave of terrorist threats.

Key words: Israel, politics, terrorism, human rights, demolition of houses, IDF, responsibility. 